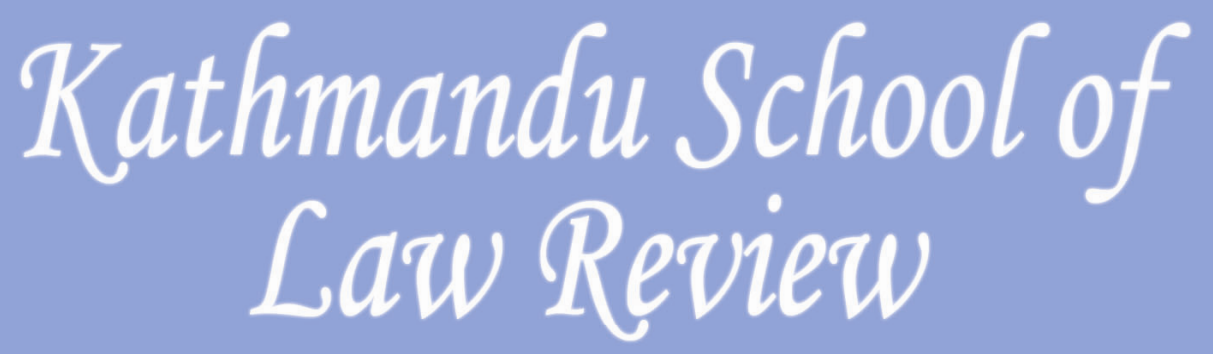

ISSN 2091-2110

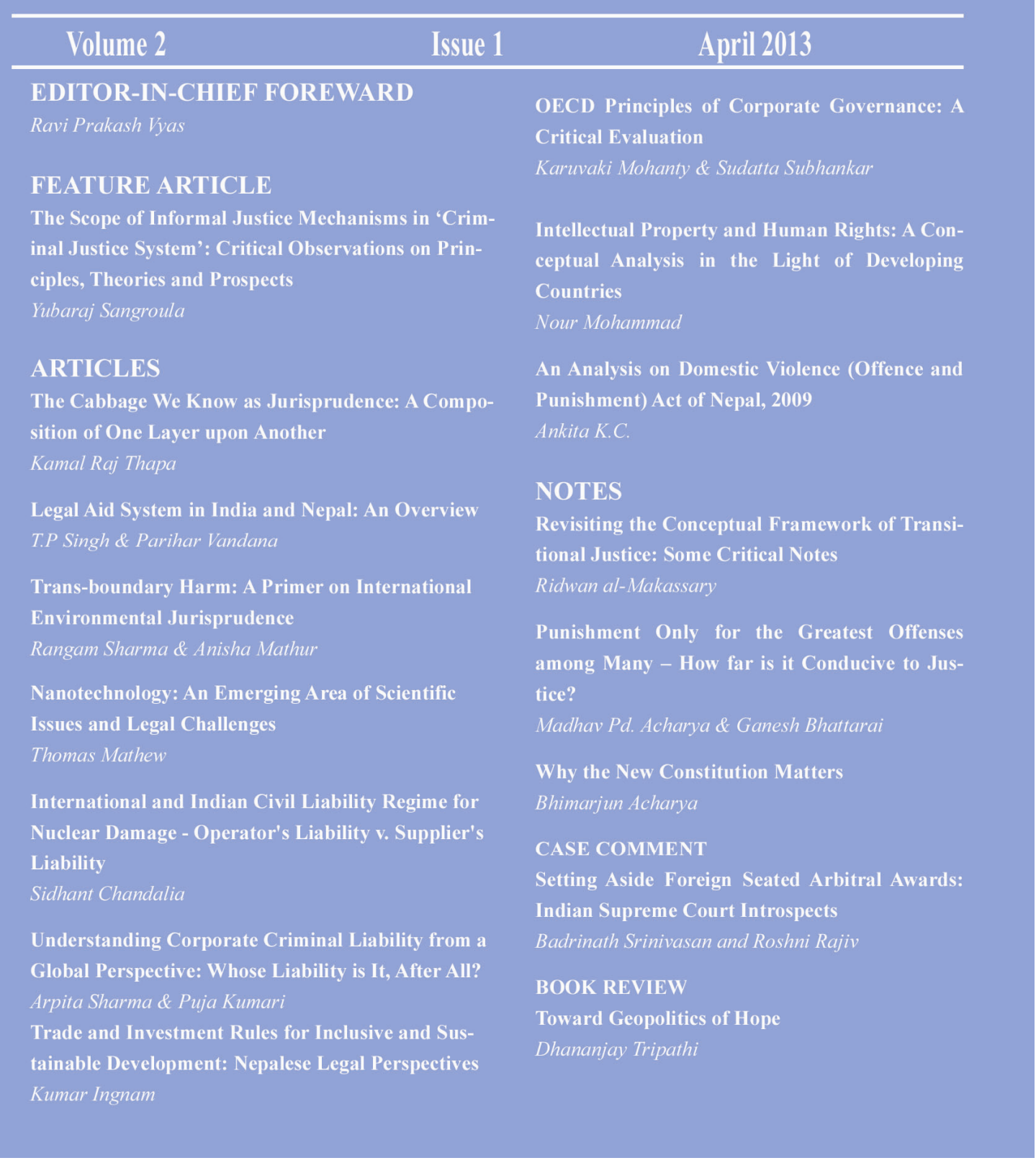




\title{
Setting Aside Foreign Seated Arbitral Awards: Indian Supreme Court Introspects
}

\begin{abstract}
Badrinath Srinivasan $^{1}$ and Roshni Rajiv ${ }^{2}$
This paper primarily provides a descriptive comment on the developments leading to the decision in BALCO from the passing of the 1996 Act and briefly analyses the effect of BALCO on arbitration in India. It provides a contextual background to the Indian Supreme Court's decision in BALCO which has received wide acclamation in the international arbitration community. It discusses on the historical background of the 1996 (Indian) Arbitration and Reconciliation Act, the case regarding Bhatia International and developments subsequent to Bhatia International and proceeds towards a descriptive comment on BALCO and its effects on Indian arbitration.
\end{abstract}

\section{Introduction}

Bharat Aluminium Co. Ltd. v. Kaiser Aluminium Co (hereinafter BALCO) ${ }^{3}$ is one of the most significant judgements on arbitration rendered by the Supreme Court of India. The judgement brings India back into the map of International Commercial Arbitration after more than a decade. $B A L C O$ overrules the much maligned judgement of the Supreme Court in Bhatia International v. Bulk Trading $S A^{4}$ where the court held that part I of the (Indian) Arbitration and Conciliation Act, $1996^{5}$ (which contains provisions related to the seat of arbitration such as those pertaining to interim measures by Indian courts, appointment of arbitrators by the Chief Justice, challenging the validity of arbitral awards among others) was applicable even to foreign arbitrations. Consequently, these provisions were made applicable even when the seat of arbitration was outside India. Since two jurisdictions exercised the functions of the arbitral seat, it meant that two jurisdictions were granted legal validity to, and exercised supervision over, arbitration. This was antithetic to international commercial arbitration. BALCO restored this imbalance by holding that part I of the 1996 Act did not apply to international commercial arbitration held outside India. Therefore,

B.A. (Law) LL.B. (S.D.M. Law College, Mangalore, India), LL.M. (West Bengal National University of Juridical Sciences Kolkata, India). Email lawbadri@gmail.com

2 B.S.L. LLB (ILS Law College, Pune, India), Licentiate Company Secretary. The authors are currently working in Public Sector Undertakings. Views stated herein are personal.

Bharat Aluminium Co. Ltd. v. Kaiser Aluminium Co. 9 SCC 552. (India 2012)

Bhatia International v. Bulk Trading SA AIR 2002 SC 1432(India) (BALCO)

Hereinafter 'Act' or '1996 Act'. 
$B A L C O$ has heralded a significant landmark in international commercial arbitration worldwide and is expected to mark a new beginning for international arbitration in India. ${ }^{6}$

\section{The Genesis of BALCO: Its Contextual Background}

Towards the end of the $19^{\text {th }}$ century, India enacted its first modern arbitration law which was based on English Arbitration Act 1899. However, a need to consolidate and amend the law relating to arbitration was felt, which subsequently led to the enactment of the Arbitration (Protocol and Convention) Act 1937 by the legislative. ${ }^{7}$ This Act sought to give effect to Geneva Protocol on Arbitration Clauses $1923^{8}$, Geneva Convention on the Execution of Foreign Arbitrated Awards $1927^{9}$ and the Foreign Awards (Recognition and Enforcement) Act $1961^{10}$ to give effect to Convention on Recognition and Enforcement of Foreign Arbitral Awards 1958. ${ }^{11}$

The Arbitration Act 1940 attracted several criticisms because the arbitral proceedings under this Act had become highly time consuming and complex. ${ }^{12}$ Moreover, these three Acts could not keep pace with international developments in arbitration, including the harmonization of United Nations Commission on International Trade Law on international commercial arbitration ${ }^{13}$ through publication of the UNCITRAL Model Law $1985 .{ }^{14}$ In 1991, India adopted the New Industrial Policy by which the country strove to achieve economic development through the adoption of market friendly practices including allowing foreign direct investment in India and abandoning anti-private sector policies. ${ }^{15} \mathrm{It}$ was felt that the then existing system of commercial dispute resolution was riddled with enormous delays and unpredictability, therefore, a new market friendly law on dispute resolution was required. India decided to adopt the UNCITRAL policy of minimum judicial interference in the arbitral process. ${ }^{16}$ Arbitration and Conciliation Ordinance 1996

6 Gary Born \& Suzanne Spears, 'International Arbitration \& India: "A Truly Excellent Judgement", (2012) 1 Indian Journal of Arbitration Law 6, 10.

7 Hereinafter '1937 Act'.

$8 \quad$ Protocol on Arbitration Clauses, Geneva (entered into force 23 July 1924) 27 LNTS 157.

9 Geneva Convention on the Execution of Foreign Arbitrated Awards (adopted 26 September 1927) 2 LNTS 301 (Geneva Convention).

10 Hereinafter '1961 Act'.

11 Convention on the Recognition and Enforcement of Foreign Arbitral Awards (adopted 10 June 1958) 330 UNTS 38 (New York Convention).

12 Guru Nanak Foundation v. Rattan Singh and Sons 4 SCC 634 (India 1981).

13 Hereinafter 'UNCITRAL'.

14 UNCITRAL Model Law on International Commercial Arbitration (adopted 21 June 1985) UN Doc A/40/17 (Model Law).

15 Sandeep S. Sood, 'Finding Harmony with UNCITRAL Model Law: Contemporary Issues in International Commercial Arbitration in India after the Arbitration and Conciliation Act of 1996' (2007) <http://works.bepress.com/sandeep_sood/1/> accessed 4 March 2013.

16 See Statement of Objects and Reasons to the Arbitration and Conciliation Bill 1995 which, inter alia provides: 'The present bill seeks to consolidate and amend the law relating to domestic arbitration, international commercial arbitration, enforcement of foreign arbitral awards and to define the law relating to conciliation, taking into account the said UNCITRAL Model Law and Rules.' (emphasis added) 
was passed which subsequently transformed into an Act by the virtue of the Arbitration and Conciliation Act 1996 which received presidential assent in August 1996. The Act was brought into force on 22 August 1996 through a notification by the Central Government in the Official Gazette. ${ }^{17}$

The Act is divided into four parts - part I contains provisions governing arbitrations where the place of arbitration is in India. This particular part applies to arbitrations which are held in India irrespective of the nationality of the parties to the arbitration. However, when the arbitration held in India has an international commercial character ${ }^{18}$, part I of the Act treats it differently to arbitrations held in India between Indian parties. Party autonomy is given more deference in the former than in the latter case. Part II titled 'Enforcement of Certain Foreign Awards' deals with enforcement of foreign awards. Part III deals with provisions pertaining to conciliation and part IV contains supplementary provisions.

Prelude to Bhatia International: Soon after the 1996 Act was passed, question arose as to whether Section $9^{19}$ thereof was applicable to international commercial arbitrations held outside India. Some high courts held that Section 9 would apply to such arbitrations since part I of the Act (which contains Section 9) is applicable to all arbitrations, whether inside or outside India. ${ }^{20}$ Some High Courts, however, held that Part I and consequently Section 9

17 Notification No. GSR. 375(E) (22 August 1996); See generally (for a detailed discussion of the historical background to the 1996 Act ) Anirudh Wadhwa et al (eds.), Justice RS Bachawat's Law of Arbitration and Conciliation ( $5^{\text {th }}$ edn, LexisNexis Butterworths 2010) 1-11.

18 Section 2(1)(f) of the 1996 Act defines International Commercial Arbitration as 'an arbitration relating to disputes arising out of legal relationships, whether contractual or not, considered as commercial under the law in force in India and where at least one of the parties is- (i) an individual who is a national of, or habitually resident in, any country other than India; or (ii) a body corporate which is incorporated in any country other than India; or (iii) a company or an association or a body of individuals whose central management and control is exercised in any country other than India; or (iv) the Government of a foreign country.'

19 Section 9 of the 1996 Act provides: 'Interim measures etc.by Court.- A party may, before, or during arbitral proceedings or at any time after the making of the arbitral award but before it is enforced in accordance with Section 36, apply to a court-

(i) for the appointment of a guardian for a minor or person of unsound mind for the purposes of arbitral proceedings; or (ii) for an interim measure or protection in respect of any of the following matters, namely:- (a) the preservation, interim custody or sale of any goods which are the subject-matter of the arbitration agreement; (b) securing the amount in dispute in the arbitration; (c) the detention, preservation or inspection of any property or thing which is the subject-matter of the dispute in arbitration, or as to which any question may arise therein and authorising for any of the aforesaid purposes any person to enter upon any land or building in the possession of any party or authorising any samples to be taken or any observation to be made, or experiment to be tried, which may be necessary or expedient for the purpose of obtaining full information or evidence; (d) interim injunction or the appointment of a receiver; (e) such other interim measure of protection as may appear to the Court to be just and convenient, and the Court shall have the same power for making orders as it has for the purpose of, and in relation to, any proceedings before it.'

20 See Suzuki Motor Corporation v. Union of India \& Anr. 1997(2) Arb.L.R 477 (Delhi); See also Dominant Offset Pvt. Ltd. v Adamovske Strojirny A.S. 1997(2) Arb. LR 335 (Del.); See also L.M.L. Ltd. v. Union of India MANU/UP/0744/1998 (DB); See also OlexFocas Pty. Ltd. v. Skodaexport Co. Ltd. 1999 (Suppl.) Arb. LR 533 (Delhi); See also Naval Gent Maritime Ltd. v. Shivnath Raj Harnarain (I) 
applied to domestic arbitrations alone. ${ }^{21}$ This question came up before the Supreme Court bench comprised of three judges.

Bhatia International: Bhatia International ${ }^{22}$ and Bulk Trading SA entered into a contract which contained an arbitration clause which provided that arbitration was to be as per the rules of the International Chamber of Commerce ${ }^{23}$. Disputes arose between the parties which led Bulk Trading to file a request for arbitration under the rules of ICC in accordance with the terms of the contract. In response, Bhatia sought interim relief under Section 9 of the Act before a lower court in India to restrain Bulk Trading from, inter alia, alienating, and transferring disposing of their business assets and properties located in India. The lower court, dismissing the maintainability plea of Bhatia, held that Indian courts had jurisdiction to entertain applications under Section 9 in international commercial arbitration.

Rejecting this contention, the Supreme Court held that part I of the Act was applicable even to international commercial arbitration held outside India; but parties could exclude the applicability of part I expressly or impliedly. The court reasoned that if part I was held to be not applicable to arbitrations held outside India; it would lead to the following anomalies:

1. There would be no law governing arbitrations held in countries that were not signatories to the Geneva Convention or the New York Convention.

2. Part I would apply to Jammu and Kashmir in all international commercial arbitration (including arbitrations held outside India) but for the rest of India, Part I would not apply to arbitrations held outside India.

3. Sections $2(4)^{24}$ and $(5)^{25}$ would be in conflict with Section $2(2)^{26}$ of the Act.

4. A party to an arbitration held outside India would have no remedy to obtain interim relief even if the assets which are the subject matter of such application for interim relief are in India.

Ltd. MANU/DE/1354/2000; Khanji Exports Pvt. Ltd. v. Shiptrade Inc. MANU/DE/1353/2000; See also Cultor Food Science Inc. v. Nicholas Piramal India Ltd. and Ors. MANU/AP/0072/2002.

21 See East Coast Shipping v M.J. Scrap 1 Cal HN 444 (1997); See also Kitechnology NV v. Unicor GmBH Rahn Plastmaschinen 1999(1) Arb. LR 452(Delhi); See also Marriott International Inc. \&Ors. v. Ansal Hotels Limited \&Anr. 2000(3) Arb. LR 369 (Delhi) (DB); See also Bharti Televentures Limited v.DSS Enterprises Private Limited MANU/DE/0600/2001, para 28.

22 Hereinafter 'Bhatia'.

23 Hereinafter 'ICC'.

24 Section 2(4) reads: '(4) This Part except sub-section (1) of section 40, sections 41 and 43 shall apply to every arbitration under any other enactment for the time being in force, as if the arbitration were pursuant to an arbitration agreement and as if that other enactment were an arbitration agreement, except in so far as the provision of this Part are inconsistent with that other enactment or with any rules made thereunder;'

25 Section 2(5) states: 'Subject to the provisions of sub-section (4), and save in so far as is otherwise provided by any law for the time being in force or in any agreement in force between India and any other country or countries, this Part shall apply to all arbitrations and to all proceedings relating thereto.'

26 Section 2(2) reads: 'This Part shall apply where the place of arbitration is in India.' 
Further the court took a view that Section 2(2) did not provide that Part I would apply "only" where the place of arbitration was in India. Therefore, the Supreme Court held:

In cases of international commercial arbitrations held out of India provisions of Part I would apply unless the parties by agreement, express or implied, exclude all or any of its provisions. In that case the laws or rules chosen by the parties would prevail. Any provision, in Part I, which is contrary to or excluded by that law or rules will not apply. ${ }^{27}$

Post-Bhatia International Developments: Supreme Court reiterated the above position in Venture Globa ${ }^{28}$ by holding that part I of the Act, including Section 34 (dealing with setting aside arbitral awards), would apply to foreign awards. After quoting Bhatia International in extenso, the Court concluded that the legislative intent in not expressly providing that part I will not apply to international commercial arbitrations outside India was to make part I apply even to such arbitrations; but by not expressly stating that part I would apply to international commercial arbitrations held outside India, the intention was to allow parties to provide by agreement that part I or any provision therein (even the non-derogable provisions of part I) would not apply.

Subsequent decisions of Indian courts conflicted with each other on the applicability of part I of the Act, especially on the issue of implied exclusion of part I of the 1996 Act in international commercial arbitrations held outside India. In certain cases, courts have held that part I was not excluded even though the venue was outside India, the substantive law of contract was a foreign law and the Act was not procedural law. ${ }^{29}$ In certain decisions, however, it has been held that in such cases part-I was impliedly excluded. ${ }^{30}$ In several cases, courts have held that part-I would be impliedly excluded if the seat was foreign and the procedural law was not the Act. ${ }^{31}$

\section{A Discourse on $B A L C O$ and its enumeration on the now overruled Bhatia International}

$27 \quad$ Bhatia International (n 4) para 32.

28 Venture Global Engineering v Satyam Computer Services Ltd. 4 SCC 190 (2008); AIR 2008 SC 1061.

29 See National Aluminium Co. Ltd. v. Gerald Metals 2004(2) Arb LR 382 (AP); See also J.K. Industries Limited v. D.S. Strategem Trade A.G. MANU/DE/8771/2007; Venture Global Engineering v. Satyam Computer Services Ltd. 4 SCC 190(2008), AIR 2008 SC 1061; Citation Infowares Ltd. v. Equinox Corporation 7 SCC 220(2009); Abbas Cashew Company v. Bond Commodities cited in <http://www.indiankanoon.org/doc/1593428/> accessed April 20, 2011.

30 Liverpool and London Steamship Protection and Indemnity Association Ltd. v. Arabian Tankers Co. 2003 (3) $\quad$ Arb LR 537 (Bom); Max India v. General Binding Corporation 112 DRJ 611 (2009); DGS Realtors Pvt. Ltd. v. Realogy Corporation MANU/DE/2115/2009; Dozco India P .Ltd. v. Doosan Infracore Co. Ltd. 6 SCC 179(2011).

31 See (for a discussion on the conflicting views of various Indian courts on the implied exclusion of Part I of the 1996) Badrinath Srinivasan, 'Arbitration and the Supreme Court: A Tale of Discordance between the text and Judicial Determination' (2011) 4 NUJS L Rev 639, 641-643. 
For many years, there were calls for reconsideration of Bhatia International. ${ }^{32}$ Although, no statutory amendment came through, the Supreme Court had the occasion to re-consider Bhatia International in the dispute in BALCO.

Facts: In April 1993, an agreement was executed between the Bharat Aluminium Co. Ltd. ${ }^{33}$ and Kaiser Aluminium Co. Ltd. containing an arbitration clause. It provided that the agreement would be governed by the Indian laws and the English law would apply in case of arbitration. ${ }^{34}$ When disputes arose, the parties duly referred the same to arbitration in England. The tribunal passed two awards which were challenged by the Bharat Aluminium in India under Section 34 of 1996 Act. The District Court, Bilaspur and the High Court of Chattisgarh dismissed the applications of Bharat Aluminium holding that the applications under Section 34 of 1996 Act for setting aside the foreign awards were not tenable. Subsequently, Bharat Aluminium appealed to the supreme court. The appeal was initially placed before a two judge bench of supreme court. However, since the two judges differed $^{35}$ regarding the interpretation of Section 2(2) of Act, subsequently the appeal was directed to be placed before the chief justice of India, who placed it before a three judge bench. Subsequently, the three judge bench passed an order that this appeal was to be placed before a five judge bench of the supreme court. ${ }^{36}$ The five judge bench conducted the hearings in the matter in the first half of 2012 and passed a detailed judgement on 6 September 2012.

32 See, F. S. Nariman, 'Ten Steps to Salvage Arbitration in India: The First LCIA-India Arbitration Lecture' (2011) 27 Arb. Int 115; See also Ministry of Law and Justice, Government of India, 'Proposed Amendments to the Arbitration \& Conciliation Act, 1996: A Consultation Paper' (April 2010) (Consultation Paper).

33 Hereinafter "Bharat Aluminium".

34 The arbitration and choice of law clause in the said agreement reads: "Article 17.1 - Any dispute or claim arising out of or relating to this Agreement shall be in the first instance, endeavour to be settled amicably by negotiation between the parties hereto and failing which the same will be settled by arbitration pursuant to the English Arbitration Law and subsequent amendments thereto. Article $17.2-$ The arbitration proceedings shall be carried out by two Arbitrators one appointed by BALCO and one by KATSI chosen freely and without any bias. The court of Arbitration shall be held wholly in London, England and shall use English language in the proceeding. The findings and award of the Court of Arbitration shall be final and binding upon the parties.

Article 22 - Governing Law - This agreement will be governed by the prevailing law of India and in case of Arbitration, the English law shall apply.'

35 The Order of two Judge Bench reads 'In the midst of hearing of these appeals, learned counsel for the appellant has referred to the three- Judges Bench decision of this Court in Bhatia International Vs. Bulk Trading S.A. \&Anr., (2002) 4 SCC 105. The said decision was followed in a recent decision of two Judges Bench in Venture Global Engineering Vs. Satyam Computer Services Ltd. \&Anr. 2008 (1) Scale 214. My learned brother Hon'ble Mr. Justice Markandey Katju has reservation on the correctness of the said decisions in view of the interpretation of Clause (2) of Section 2 of the Arbitration and Conciliation Act, 1996. My view is otherwise. Place these appeals before Hon'ble CJI for listing them before any other Bench." BALCO (n 4) para 1.

36 Several other cases were decided along with the case by the constitutional bench since common questions arose. 
Decision: The constitutional Bench has discussed and made pronouncements on various aspects. Hence, it would do good to summarize the decision of the court.

\section{a) Interpretation of Section 2(2) and Scope of part I}

- In paragraph 14(b) of Bhatia International, it was held: '(b) Lead to an anomalous situation, inasmuch as Part I would apply to Jammu and Kashmir in all international commercial arbitrations but Part I would not apply to the rest of India if the arbitration takes place out of India.' The conclusion in the above paragraph of Bhatia International is incorrect. Section 1(2) is exact to the Arbitration Act 1940 (1940 Act). The said section 1(2) reads 'It extends to the whole of India (except the State of Jammu and Kashmir).' The object of the proviso to Section $1(2)^{37}$ was only to incorporate the special provisions pertaining to international commercial arbitration. These aspects were not dealt with under the 1940 Act and therefore the proviso was necessary. No anomaly would be created as Section 2(2) would apply equally to arbitrations in Jammu and Kashmir and the courts in Jammu and Kashmir would not have jurisdictions as regards international commercial arbitration held outside India. Section 2(2) is not therefore affected by the said proviso. Purely domestic awards, which have no international flavour, would be governed by the relevant arbitration statute of Jammu and Kashmir. ${ }^{38}$

- Section 2(2) bars jurisdiction of Indian courts as regards arbitration held outside India. The opposite conclusion reached in Bhatia International is overruled. The exclusion of 'only' in Section 2(2) is not a case of casus omissus and the omission is not a mistake. A plain reading of Section 2(2) makes it clear that part I do not apply to arbitrations held outside India. ${ }^{39}$

- The relevant Model Law in its article $1(2)^{40}$ uses the word "only" as it contains exceptions to the territorial applicability and certain provisions such as interim measures are applicable even for arbitrations held outside the relevant country. Therefore 'only' is to stress the fact that except for such provisions, the Model Law was applicable to the relevant country alone. Since those exceptions have not been retained in the 1996 Act, use of 'only' was not necessary in Section 2(2). In fact the

37 Proviso to Section 1(2) of the 1996 Act reads 'Provided that parts I, III and IV shall extend to the State of Jammu and Kashmir only in so far as they relate to international commercial arbitration or, as the case may be, international commercial conciliation.'

$38 \quad B A L C O(\mathrm{n} 4)$ paras 54-58; See also (for a detailed critique of BALCO on this aspect) Badrinath Srinivasan, 'Review of the Consultation Paper on Proposed Amendments to the Arbitration and Conciliation Act, 1996- Part I' (2010) < http://practicalacademic.blogspot.in/2010/05/review-ofconsultation-paper-on.html> accessed 8 March 2013.

39 Ibid paras 60-63.

40 'The provisions of this Law, except articles 8, 9, 35 and 36 apply only if the place of arbitration is in the territory of this State.' (emphasis added). Model Law (n 14) art 1(2). 
Swiss Private International Law Act 1987 and the English Arbitration Act, 1996 have dropped off 'only' as well. ${ }^{41}$

- If part I was applicable to international commercial arbitrations outside India, certain words would have to be added by the court to Section 2(2) to the effect, which is not permissible. ${ }^{42}$

- Bhatia International's conclusion that Section 2(2) conflicts with Sections 2(4) or (5) is erroneous. Section 2(4) only deals with arbitrations under other enactments. This provision has to be read in conjunction with Section 2(2) and would operate only as regards arbitrations in India under any enactment in force. This is in consonance with Article 245 of the Constitution which provides that parliament may make laws for the whole or part of India. Similarly Section 2(5) must be read in conjunction with Section 2(2). The phrase 'all arbitrations' in Section 2(5) is to be read with as all arbitrations in India within the scope of Section 2(2). ${ }^{43}$

- It was contended that Section $2(7)^{44}$ indicates that part I would apply to arbitrations outside India. This does not in any way dilute the adherence to the territoriality principle adopted in the 1996 Act nor does it provide for delocalized arbitration. The need for defining 'domestic awards' under Section 2(7) was to distinguish it with 'foreign awards' which are covered by part II of the Act. Further, the definition also clarifies that even if the award was rendered in an international commercial arbitration held in India, such award is a domestic award. ${ }^{45}$

- The definitions provided in sections contained in part I and II clarify the respective applicability of these parts. Section 2 begins with the expression 'In this part, unless the context otherwise require...'. Similarly sections $44^{46}$ and $53^{47}$ give the interpretation of foreign awards for the purposes of chapters I and II of Part II. ${ }^{48}$

- It was contended that Section 9(b) ${ }^{49}$ of the 1961 Act, not retained in the 1996 Act, provided that nothing there was applicable to award in an arbitration agreement governed by Indian law. There is no link between the non-inclusion of 9(b) in the

$B A L C O$ (n 4) paras 68, 77.

Ibid para 80.

$B A L C O$ (n 4) paras 81-85.

Section 2(7) of the 1996 Act reads 'An arbitral award made under this Part shall be considered as a domestic award.'

$45 \quad B A L C O$ (n 4) para 88.

46 Section 44 of the 1996 Act reads 'In this Chapter, unless the context otherwise requires," foreign award" means an arbitral award on differences between persons arising out of legal relationships.'

47 Section 53 of the 1996 Act reads 'In this Chapter" foreign award" means an arbitral award on differences relating to matters considered as commercial under the law in force in India."

$48 \quad B A L C O$ (n 4) para 89.

49 Section 9(b) of the 1961 Act reads 'Saving: Nothing in this act shall...(b) Apply to any award made on an arbitration agreement governed by the law of India.' 
1996 Act and the applicability of Part I to foreign arbitrations. The purpose behind Section 2(7) of the 1996 Act was to foreclose the possibility that arbitration in India between two foreign parties should be construed to be a non-domestic arbitration and provisions pertaining to foreign awards would be invoked to enforce such an award in India. $^{50}$

- Section 2(1)(e) which defines 'courts' deals with courts which would exercise supervisory control over the arbitral process. Thus, if neither party belongs to Delhi but both arbitrate in Delhi, the Delhi courts would have supervisory jurisdiction over the arbitral process. This is apart from the courts which would have had the jurisdiction as cause of action arose within such court's jurisdiction. This has no relevance to the applicability of part I of the Act to non-domestic arbitrations. Section 20 which provides that parties could agree to the place of arbitration and that in case of failure by parties the tribunal will determine the appropriate place, is only meant to operate in arbitrations where place is India but parties have not selected the particular location in India. Further, for practical considerations a tribunal may meet even outside India as provided in Section 20(3). ${ }^{51}$ Thus, there is a distinction between 'seat' and 'venue'. An agreement has to be construed independently to see if the foreign 'seat' would be read as in fact providing merely for a venue where the hearings would be held, in view of the choice of the 1996 Act as being the curial law or whether the specific designation of a foreign seat, necessarily carrying with it the choice of that country's arbitration/ curial law, would prevail over and subsume the conflicting selection choice by the parties of the 1996 Act. If the agreement provides for an Indian seat, part I would be applicable. If it provides for a foreign seat, part I would be inapplicable to the extent inconsistent with the arbitration law of the seat, even if the agreement states that the 1996 Act shall govern the arbitration proceedings. ${ }^{52}$

\section{b) Choice of Foreign Seat acts Akin to Exclusive Jurisdiction Clause}

- The choice of a foreign country as the seat necessarily implies that the law of the seat regarding conduct and supervision of arbitration will apply. Therefore, if the seat is a foreign country, part I would not be applicable to enable Indian courts to exercise supervisory jurisdiction. Even if parties agree that 1996 Act would be the procedural law, it would only mean that the parties have contractually imported from the 1996 Act, those provisions which are concerned with the internal conduct

\footnotetext{
$50 \quad B A L C O$ (n 4) paras 91-94.

51 Section 20(3) reads 'Notwithstanding sub-section (1) or sub-section (2), the arbitral tribunal may, unless otherwise agreed by the parties, meet at any place it considers appropriate for consultation among its members, for hearing witnesses, experts or the parties, or for inspection of documents, goods or other property.'

$52 \quad B A L C O$ (n 4) paras 96-99.
} 
of their arbitration and which are not inconsistent with the mandatory provisions of the English Procedural Law/Curial Law. ${ }^{53}$

\section{c) Interpretation of Section 28}

- Section 28 provides an option in a domestic international commercial arbitration for the parties to choose a different substantive contract law and is not indicative of the intent to make part I applicable to foreign arbitrations. ${ }^{54}$

- There is a complete segregation between part I and II in the Act. Regulation of arbitration consists of four steps (a) commencement, (b) conduct, (c) challenge and (d) recognition and enforcement. Part I deals with all the four but as regards domestic arbitration while part II deals with only (a) commencement and (b) recognition and enforcement. Thus, the conduct and the challenge of arbitrations are to be done in the country having supervisory jurisdiction over the arbitration. This is in consonance with the schemes in international instruments such as the New York Convention and the UNCITRAL Model Law on international commercial arbitration. ${ }^{55}$

- Use of the expression "notwithstanding anything contained in part I, or in the Code of Civil Procedure 1908", in section 45 of the Arbitration Act 1996 do not indicate the extra territorial applicability of part I. These were the expressions used in the 1961 Act and since the 1996 Act is also a consolidating statute, it is not rare for a consolidating Act to retain the expressions used in the previous Acts. ${ }^{56}$

\section{d) 1996 Act, Foreign Awards and New York Convention}

- It was argued that the expression ' enforcement of a foreign award' may be refused when the award has been set aside or suspended under the law of which that award was made in Section 48(1) (e) indicates part I is applicable to foreign arbitrations. It is not so. The said provision has been imported from the New York Convention and it recognises that the two courts have jurisdiction to annul and does not confer jurisdiction on a court to annul an award made outside the jurisdiction of the seat. It may be noted that the second alternative, that is, under the law of which the Award was made was inserted to state that in case the national legislation in the seat did not

$53 \quad B A L C O(\mathrm{n} 4)$ para 122.

54 Section 28(1) (b) of 1996 Act reads as 'Rules applicable to substance of dispute :In international commercial arbitration- i. the arbitral tribunal shall decide the dispute in accordance with the rules of law designated by the parties as applicable to the substance of the dispute; ii. any designation by the parties of the law or legal system of a given country shall be construed, unless otherwise expressed, as directly referring to die substantive law of that country and not to its conflict of laws rules; iii. failing any designation of the law under clause (a) by the parties, the arbitral tribunal shall apply the rules of law it considers to be appropriate given all the circumstances surrounding the dispute.'

$55 \quad B A L C O(\mathrm{n} 4)$ paras 124-129.

$56 \quad B A L C O(\mathrm{n} 4)$ paras 130-131. 
permit challenge, it could be made in the law under which the award was made. Thus, the 'second alternative' is not really an alternative but only operates in absence of provision of challenge in the 'first alternative' that is, the law of the seat. A similar situation resulted in Venture Global where the award was set aside under the laws governing the applicable law, Indian law. Furthermore, it is to be noted that the expression 'under the law' in section 45 is not a substantive law of contract but a procedural law of arbitration. ${ }^{57}$

\section{e) Applicability of Section 9 to Foreign Arbitrations}

- As regards applicability of section 9 to foreign arbitrations, the power cannot be imputed to a court by the process of interpretation and such would violate the principle of territoriality in section 2(2) of the Act. ${ }^{58}$

- In Bhatia International, a non-convention award was interpreted to be included in part I of the 1996 Act, as the court considered it to be a lacuna that the said Act did not cover such awards. There is no such lacuna. ${ }^{59}$

- Section 9 has been placed in part I of the Act. Since part I does not apply to foreign arbitrations, neither does section 9. Further, since part II does not contain a provision for interim measures, Indian courts do not have the power to grant interim measures in foreign arbitrations. ${ }^{60}$

- Bhatia International was wrong to interpret the words 'in accordance with Section 36 ' to go only with 'after making the arbitral award' as regards foreign arbitration interim measures under section 9 are available before or during the arbitration but not after the award is passed. The interpretation is erroneous as the text of section 9 does not support it. If section 9 is extended to foreign arbitrations, it would violate the territoriality principle enshrined in section $2(2) .{ }^{61}$

- Just because the remedies against the award in a foreign seat are more onerous does not mean that part I should be applicable to such arbitrations. The parties have chosen their seat of arbitration by consensus and the remedies available against the award is a consequence of such a choice. A choice of foreign seat, likewise, implicitly means that parties would not have the right to seek interim measures from courts. $^{62}$ If by interpretation the court makes part I applicable to foreign arbitrations, it would amount to 'naked usurpation of the legislative function under the thin guise of interpretation.' 63

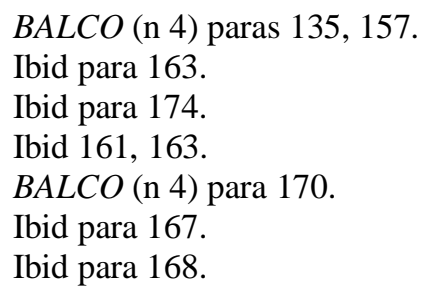


- The intention of the authors of the 1996 Act is available in the text of the statute and the context of the provisions. Hence, Bhatia International was wrong to assume the role of 'finishers, refiners and polishers' of the Act.

\section{f) Absence of Provisions on Interim Measures by Court in Foreign Arbitrations}

- Even a suit for interim relief pending arbitrations is not permitted under the Indian law. Existence of a cause of action is essential to file a civil suit. In suits seeking interim relief pending arbitrations, there is no cause of action. ${ }^{64}$ An interlocutory injunction is available only in a civil suit claiming some final relief and such an injunction must be a part of some substantive relief claimed. An application for interim relief cannot stand on its own and is dependent on a pre-existing cause of action.

- This position of law has been affirmed in various judicial pronouncements such as Cotton Corporation of India v. United Industrial Bank ${ }^{65}$, Ashok Kumar Lingala v. State of Karnataka ${ }^{66}$ among others.

\section{g) Prospective Applicability}

Therefore, Bhatia International and Venture Global are clearly erroneous. Since they have been applied by numerous courts, the law declared in this judgement would be applicable prospectively to all arbitration agreements executed hereafter.

\section{The Effects of $B A L C O$}

The impact of $B A L C O$ on judicial interference in foreign arbitration is clear. The choice of a foreign seat would operate as an exclusive jurisdiction clause and would exclude the applicability of part I of the Act. The decision spells out the correct position law as regards this aspect. ${ }^{67}$ Apart from this, the two aspects of $B A L C O$ that require further discussion are: ${ }^{68}$

64 See Code of Civil Procedure 1908 (Indian) Order VII, rules 1, 11(e); See also Specific Relief Act, 1963 (Indian), ss. 14(2), 37, 38.

65 Cotton Corporation of India v. United Industrial Bank AIR 1983 SC 1272.

66 Ashok Kumar Lingala v. State of Karnataka 1 SCC 321(2012).

67 See (for a critique of $B A L C O$ ) V. Niranjan \& Shantanu Narvane, 'Bhatia International Rightly Overruled: The Consequences of Three Errors in BALCO' (2012) 9 SCC J-26 (where the authors point out three 'not prominent', 'subsidiary' errors in BALCO which do not 'apply to foreign arbitration').

68 There is also another aspect of $B A L C O$ that has been criticized. As regards arbitration held in India, the appropriate court which would have jurisdiction in respect of the arbitral proceedings is the court, but for the arbitration, would have jurisdiction under the Code of Civil Procedure 1908(Indian). It has been suggested that BALCO holds that in addition to such a court, the appropriate court in the seat of arbitration would also have jurisdiction. For detailed analysis of this issue. Ibid 33; Chakrapani Misra \& Arijeet Mukherjee, 'The ViewpointTerritorial Jurisdiction of Civil Courts for Recourse against Arbitral Award' (5 March 2013). $<$ http://barandbench.com/brief/1/3265/the-viewpoint-territorial-jurisdiction-of-civil-courts-forrecourse- against-arbitral-award> accessed 6 March 2013. 
Availability of Interim Measures in India in Foreign Seated Arbitrations: The supreme court held in $B A L C O$ that a party cannot approach the Indian courts for interim measures in foreign arbitrations. ${ }^{69}$ This is an important conclusion that might affect the parties' choice of foreign seats in Indian contracts in the future. The non-availability of interim measures in foreign arbitration was canvassed as an argument in $B A L C O$ in favour of applying Part I of the Act to foreign arbitrations. ${ }^{70}$ The court however rejected these arguments and held that sincesection 9 has been placed in part I of the Act and since part I does not apply to foreign arbitrations, neither does section $9^{71}$ It was further held that since part II did not contain a provision for interim measures, Indian courts do not have the power to grant interim measures in foreign arbitrations. ${ }^{72}$ Further, the court held that the (Indian) Code of Civil Procedure 1908 did not contain a provision for filing a suit merely for obtaining interim relief. ${ }^{73}$ Therefore, the court concluded that there was no law for interim measures in foreign arbitrations. It has been argued that the supreme court was not right in holding that a party could not apply for interim measures under the Code of Civil Procedure 1908 in an absence of express provision in the 1996 Act. ${ }^{74}$ In any case, the court's decision that interim measures would not be available in foreign seated arbitration is an important area of concern for those parties wanting to agree to a foreign seated arbitration. Although, in such cases, recourse in respect of interim measures would be to approach the arbitral tribunal itself, the efficacy of interim orders of the tribunal especially when the subject of interim measures is located in India is questionable.

Prospective Applicability: Another aspect of $B A L C O$ has received criticisms from several quarters. Having overruled Bhatia International, the Supreme Court held:

The judgment in Bhatia International was rendered by this Court on 13th March, 2002. Since then, the aforesaid judgment has been followed by all the high courts as well as by this Court on numerous occasions. In fact, the judgment in Venture Global Engineering has been rendered on 10th January, 2008 in terms of the ratio of the decision in Bhatia International. Thus, in order to do complete justice, we hereby order, that the law now declared by this Court shall apply prospectively, to all the arbitration agreements executed hereafter. ${ }^{75}$

Thus, Bhatia International and Venture Global were hold good for arbitration agreements preceding $B A L C O$. This part of the judgement has been criticised because for the coming years, there would be two parallel regimes which the courts have to take stock of - the Bhatia International regime and the BALCO regime and that the former regime would stay

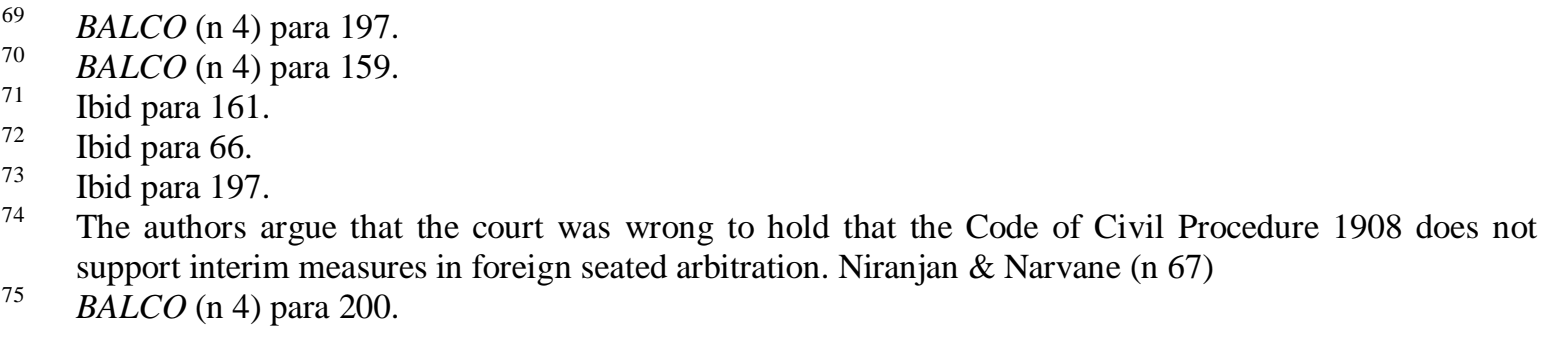


for several years especially in respect of long term agreements. ${ }^{76}$ Besides, it has been argued that the judgement puts claimants under arbitration agreements which were concluded prior to Bhatia International in a worse position for having relied on the right law as affirmed by BALCO than those who relied on the wrong position stated in Bhatia International. ${ }^{77}$ Lastly, it has been argued that the supreme court should not have made $B A L C O$ prospectively applicable to agreements as Bhatia International and subsequent decisions did not affect the validity of arbitration clauses providing for the seat abroad but held that in such cases, Indian courts would have jurisdiction. ${ }^{78}$ Consequently, it was argued that $B A L C O$ should have applied prospectively to commencement of proceedings.

The criticisms may not be altogether justified for the following reasons:

- In a hypothetical scenario, an Indian party and an American party agree to London arbitration in their contract. They also agree that, except for section 9 (interim measures from the court), part I of the Act would not apply to such arbitration. In such a scenario, as per Bhatia International, part I of the Act save section 9 would be excluded and parties could approach an Indian court for interim measures. Thus, there was an expectation that parties to the contract could approach the Indian courts for interim measures under section 9 despite the non-applicability of other provisions of part I. If Bhatia International were not overruled prospectively, the parties' expectation would have been put to serious jeopardy as, having drafted the arbitration clause in accordance with the prevailing law, the right to approach the Indian court under section 9 would have been lost due to a subsequent change in the law. It is obvious that parties draft contracts on the basis of the law as it was prevailing at that time. Hence, it was just on the part of the Supreme Court to overrule Bhatia International from the date of judgment in BALCO. ${ }^{79}$

- BALCO's prospective application has been criticised with the following hypothetical scenario: if a thirty year agreement is signed on 5 September 2012, a dispute arises in the year 2027 and is referred to arbitration, the award under such arbitration could be subject to challenge in the Indian courts as the Bhatia International regime would still govern it. ${ }^{80}$ On the face of it, this contention seems to be valid. However, three points are worth noting here:

76 Sumit Rai, 'Indian Supreme Court Overrules Bhatia International - Or Does It?' (2012) <http://blogarbitration.com/2012/09/06/indian-supreme-court-overrules-bhatia-international-or-does-it/> accessed 6 March 2013.

77 Niranjan \& Narvane (n 67); SK Dholakia\& Aarthi Rajan, 'Not Three but Half an Error in BALCO: Bhatia International Rightly Overruled' (2013) 1 SCC J-81.

78 Ashish Chugh, 'The Bharat Aluminium Case: The Indian Supreme Court Ushers In a New Era' (2012) $<$ http://kluwerarbitrationblog.com/blog/2012/09/26/the-bharat-aluminium-case-the-indian-supremecourt-ushers-in-a-new-era/> accessed 6 March 2013.

79 The authors argue that the court's prospective application was 'understandable'. See Born \& Spears (n 6) 9.

80 Sumit Rai, 'Indian Supreme Court Overrules Bhatia International - Or Does It?' (2012) 
- One, after a slew of judgements including Yograj Infrastructure Ltd. v. Ssang Yong Engineering and Construction Co. Ltd. $(I)^{81}$ and $(I I)^{82}$, the Bhatia International regime has been rationalised to some extent, although not satisfactorily. Hence, it is not in all cases that the foreign award could be set aside in Indian courts.

- Two, long term agreements are generally drafted in India with the help of legal counsel. In such cases, it is not unreasonable to expect that parties would have agreed to a clause that would either exclude part I fully or selectively.

- Three, even if part I has not been excluded in full or in part in such agreements, nothing prevents parties to such long term contracts to renegotiate the arbitration clauses and amend their arbitration clauses, in which case the $B A L C O$ regime would be applicable. ${ }^{83}$

Another criticism against this aspect is that the supreme court did not explain whether the appellants in the case established reliance of the principles of prospective overruling or if the court came to the conclusion that the case presented an exceptional situation necessitating the use of the said doctrine. ${ }^{84}$ It is submitted that this criticism is dwarfed by the harm that would be done to the expectations of parties had Supreme Court not applied the said doctrine to arbitration agreements entered into from the date of the judgement. The criticism seeks to sacrifice practicality at the altar of technicality.

- The critique previously noted that $B A L C O$ puts claimants under arbitration agreements which were concluded prior to Bhatia International in a worse position for having relied on the right law as affirmed by $B A L C O$ than those who relied on the wrong position stated in Bhatia International is also not wholly correct. ${ }^{85}$

The contention that the prior to Bhatia International, part I of the 1996 Act was applicable only to domestic arbitrations and not foreign arbitrations is not wholly correct. There are several decisions of high courts which are testimonial to the contention that part I would

<http://blogarbitration.com/2012/09/06/indian-supreme-court-overrules-bhatia-international-or-does-it/> accessed 6 March 2013.

81 Yograj Infrastructure Ltd. v. Ssang Yong Engineering and Construction Co. Ltd. (I)AIR 2011 SC 3517,9 SCC 735(2011).

82 MANU/SC/1495/2011.

83 Whether parties would be willing to renegotiate their arbitration clauses is a critical question. Assume that parties had agreed to a hypothetical clause mentioned above. The right to approach the Indian court under Section 9 for interim measures would be available to the American party. However, if the parties amend their arbitration clause after 06.09.2012, BALCO would not permit the American party to approach the Indian courts. Therefore, renegotiation of arbitration clauses may not happen.

84 Niranjan \& Shantanu Narvane (n 67); Contradicts with Dholakia \& Aarthi Rajan, 'Not Three but Half an Error in BALCO: Bhatia International Rightly Overruled' (2013) 1 SCC J-81, 98-99.

85 V. Niranjan \& Shantanu Narvane, 'Bhatia International Rightly Overruled: The Consequences of Three Errors in BALCO' (2012) 9 SCC J-26,43-44; Contradicts with SK Dholakia \& Aarthi Rajan, 'Not Three but Half an Error in BALCO: Bhatia International Rightly Overruled'(2013) 1 SCC J-81, 99 (affirming the said criticism). 
apply even to foreign arbitrations. ${ }^{86}$ Further, there are several cases where Bhatia International was applied to the claims under arbitration agreements concluded prior to the judgement in Bhatia International. ${ }^{87}$ Hence, the criticism that Bhatia International puts preBhatia International parties to arbitration agreements in a worse position is flawed. Claimants whose basis is agreement concluded prior to Bhatia International virtually sail in the same boat as those who did when Bhatia International was not overruled.

Even assuming the correctness of the contention that BALCO puts the pre-Bhatia International claimants in a worse position even though they relied on the correct position of law, the same would not become a fit case for review as was contended, ${ }^{88}$ considering the practical difficulties that parties who relied on Bhatia International and drafted their arbitration agreements would face.

In any case, these minor criticisms do not refute the fact that 6 September 2012 would be remembered as a day when India shook off its anti-arbitration allegations. However, it remains to be seen if the judiciary is willing to go ahead and undertake further reform in its domestic arbitration law.

$* * * * * * * * * * * * * * * * * * *$

86 See Suzuki Motor Corporation v. Union of India Anr. 1997(2) Arb.L.R 477 (Delhi); See also Dominant Offset Pvt. Ltd. v. Adamovske Strojirny A.S 1997(2) Arb. LR 335 (Delhi); See also Olex Focas Pty. Ltd. v. Skoda export Co. Ltd. 1999(Suppl.) Arb. LR 533 (Delhi); See also Naval Gent Maritime Ltd. v. Shivnath Raj Harnarain (I) Ltd. MANU/DE/1354/2000; See also Khanji Exports Pvt. Ltd. v. Shiptrade Inc. MANU/DE/1353/2000; See also Cultor Food Science Inc. v. Nicholas Piramal India Ltd. and Ors. MANU/AP/0072/2002.

$87 \quad$ See Venture Global Engineering (n 28).

$88 \quad$ Niranjan \& Narvane (n 83) 44. 